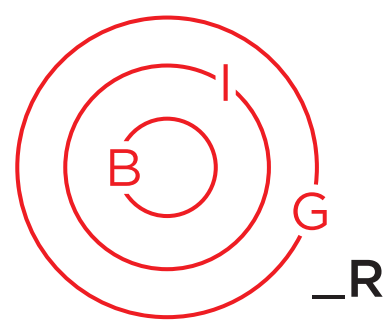

ESSAY

SPECIAL ISSUE

\title{
Israel / Palestine Borders and the Impact of COVID-19
}

\author{
David Newman *
}

\begin{abstract}
This short paper reviews the ways in which the Israeli government has managed the impact of COVID-19, with a special emphasis on the diverse border regimes-from the national to the personal. Israel has experienced two distinct phases of COVID-19, the first involving relatively low infection rates, jumping to high figures during a second phase. Two distinct borders are emphasized, the national airport through which ninety percent of travelers in and out of the country enter and which has been virtually closed down during most of the COVID-19 period, and the barriers operating between Israel and the West Bank, through which tens of thousands of Palestinian workers commute daily into Israel for employment, many of whom are now unable to work due to COVID-19 related restrictions on their movement across the border.
\end{abstract}

\section{Introduction}

Due to the political tensions concerning Israel, the country has always had a tightly controlled border regime. Entry into the country consists of a number of distinct systems of control, the major points of entry (and exit) being at the international airport located in the centre of the country for almost all foreign visitors and tourists (with limited entry and exit through

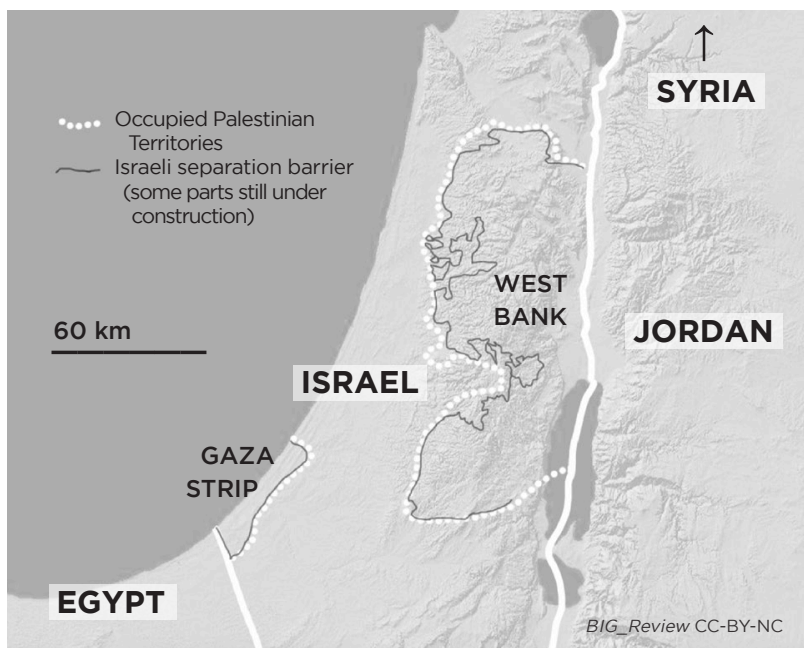

seaports or at border crossings with neighbouring countries Jordan and Egypt), and the daily movement of Palestinian workers from the Occupied Territories in the West Bank in and out of Israel across the tightly controlled Separation Barrier, which, to all effects, operates as a national border for the Palestinians, but not for Israeli citizens who move across without any restrictions or inspections.

During the first eight months of the pandemic, the airport and other international borders have largely been closed, with limited re-openings for foreign travel depending on the ups and downs of coronavirus infections. The border limiting Palestinian movement was initially closed but this has now returned to a pre-COVID-19 situation albeit with much less movement depending on the demands of an Israeli economy, parts of which have been shut down during the period.

\section{COVID-19 Phases}

Israel has undergone two distinct phases regarding the impact of COVID-19. The first stage, experienced during the first three months March-May was characterised

\footnotetext{
* David Newman, PhD, professor of Geopolitics in the Department of Politics and Government at Ben-Gurion University, Israel. Contact newman@bgu.ac.il
} 
by extremely low rates of infection and mortality, one of the lowest in the world, while the second stage (which is still being experienced at the time of writing), following what many commentators see as the opening up of the school and business systems too early, have experienced higher and growing infection rates, although this has not, as yet, translated itself into high death rates. As of the end of July 2020, the total number of COVID-19 related deaths remained below 500 during the first phase, following the initial onset of the virus in late February, early March.

This was seen to be at odds with the gradual opening of many public places, including shopping malls, prayer houses (Jewish, Moslem and Christian), the beaches and the growing number of people attending demonstrations against the government and Prime Minister Netanyahu for what they perceive as a failure of his policy, at least in Stage 2 of the virus, and for the charges of corruption against him (presently the subject of court proceedings). The lack of compliance to wear masks at such events has resulted in heavyhanded policing, the imposition of fines, and much protest against a policy which is no longer as clear as it was in the first phase of the virus.

The imposed quarantine for anyone arriving in the country, regardless of point of origin, was also disregarded by many during the early phases, but following media coverage of this, the government have imposed stricter regulations, random surveillance to encourage compliance, and the imposition of heavy fines for those not carrying out the regulation.

Notwithstanding, numbers increased dramatically through August and September, resulting in a second period of lockdown, including the major Jewish festival periods when it is normal for large gatherings to take place. This included the closing of the synagogues, mosques and prayer houses, the shopping malls and the public spaces such as parks and beaches, emphasizing the personal and family nature of borders rather than the national and international ones. At the time of writing, end of October, Israel is slowly relaxing its COVID-19 movement restrictions as it comes out of the Second Phase, albeit much more cautiously than it did following what was believed to be the First and only phase.

\section{The Nature of Israel's Borders-Points of Entry and Exit}

Some ninety percent of the incoming and outgoing movement to and from the country takes place at one point-the Ben Gurion international airport. The country's land passages to neighbouring countries are limited. The borders with Lebanon and Syria to the north are completely sealed and Israel remains in a State of War with both countries. There are three land crossings with Jordan, one of which, the Allenby bridge close to the town of Jericho, is exclusively for the use of Palestinians from the occupied West Bank. Two other land crossings, one in the far north of the country and the other in the south, linking the crossborders towns of Eilat and Aqaba, are limited to a small amount of tourism which, even at the best of times, is not significant. A single land border crossing point with Egypt at Taba, is also limited to tourism, mostly Israelis who travel into Sinai during holiday periods.

The only movement of workers across these borders were the daily flow from Aqaba in Jordan to work in the Israeli tourist industry in Elat, but given the total collapse of the tourist market, this was no longer necessary once COVID-19 had set in, and has only been partially renewed with the opening of the hotels in June.

The international airport was, for a short time, completely closed to movement, excepting the return of Israelis on rescue flights from different parts of the world. This hit the tourist industry hard, especially during the week of the Passover festival in late March, early April, a period when it is normal for increased movement through the airport-of Israelis seeking to go on vacation elsewhere, balanced by the inflow of religious Jews from around the world come to spend the festival period in Israel. None of this took place as a result of COVID-19.

Even during the first phase, it was estimated that between a third to a half of the infections which did occur were from Israelis returning from countries, especially North America and western Europe, which had high infection rates, and before a blanket policy of two-weeks home quarantine was put into effect at a later stage-a policy which applies today for anyone coming into Israel on the few flights which have started to operate.

The Israel national airline, El Al, has completely shut down, and its planes have been used for some rescue flights of Israelis stranded around the globe, and for the import of necessary medical equipment which the government purchased to help combat those infected by the virus. At the time of writing, $\mathrm{El} \mathrm{Al}$ is due to resume its operations in mid-August, but given the sudden growth of infected people in the second phase of the virus, this could be delayed even further.

Due to its geopolitical situation, Israel has a strong internal security apparatus, and the government has used this to impose tracking and surveillance of infected individuals. While the effectiveness of existing security technologies enabled almost instant implementation, this has raised serious questions concerning the agencies which have been co-opted and the intrusion of security apparatus into civilian life. Many see this, rightly, as an infringement of basic democratic procedures, and are worried that in a post 
Borders in Globalization Review | Volume 2 | Issue 1 | Fall/Winter 2020

Newman, "Israel / Palestine Borders and the Impact of COVID-19"

COVID-19 era, the security control will not be released as quickly as it was imposed.

\section{Group and Personal Borders-Religious Gatherings and Demonstrations}

A particular problem has been the gathering of religious people for daily and Shabat prayers in their synagogues and mosques, where people come into close contact with each other and which proved to be one of the early sources of the spread of the virus. All places of worship were initially shut down, but were gradually opened up to limited numbers (initially up to ten which constitutes a quorum required for community prayer services, and then up to nineteen, assuming that once the number reached twenty they would then split into two separate groups in separate locations). Throughout Israel, people came together in small groups in neighbouring gardens or neighbouring balconies in apartment blocs as an alternative form of group worship rather than congregating in an enclosed space or building. This constitutes a classic case of personal and home borders and the way they have been used to impose order in a localized spatial context.

The ultimate process of bordering was to be encountered at the ancient Western Wall in the Old City of Jerusalem, a place of mass pilgrimage for Jewish worshippers from throughout the world. Initially, the Wall plaza was shut down altogether, with a single prayer service of ten people taking place (where there might normally be tens of thousands) and broadcast through ZOOM or YouTube to the rest of the world. Following its partial re-opening, the numbers of worshippers was limited, while the plaza has been divided by temporary borders / dividers, enabling the formation of numerous small and separate prayer groups.

Another important land border is that of the Separation Fence / Barrier / Wall separating Israel from the West Bank and the Gaza Strip. In the case of Gaza, the border has been sealed for a number of years, resulting in a perpetual siege of the Gaza Strip, mostly by Israel, along the east and north borders as well as the Mediterranean Sea to the west, and also by Egypt along the south border. With the exception of missiles, incendiary balloons, controlled movement of goods from Israel into Gaza, and occasional emergency cases requiring medical attention (although far too many have been prevented), almost no movement takes place across this border, a continuation of the existing situation pre-COVID-19.

\section{The West Bank Separation Barrier Border}

This is different with respect to the West Bank. Five major border crossing points, increasingly resembling heavily fortified international borders, have been constructed along the length of the Separation Barrier during the past fifteen years. While Israelis have always been free to travel in and out of the West Bank (although the vast majority choose not to, either for fear of their own safety or because they refuse to set foot in Occupied Territories), Palestinian entry into Israel is limited to a relatively small number, approximately 100,000, who have licences to work inside Israel, mostly as the country's cheap and menial labour. Those with licences undergo selective border inspections and interrogations, are only allowed into Israel on foot, where their employers wait for them with buses and vans to ferry them directly to their places of work. Such movement is on a daily basis, entering into Israel early in the morning (around 5-6 AM) and returning to the West Bank between 3-4 in the afternoon. With few exceptions, no overnight stays inside Israel were allowed.

With the outbreak of the virus, Israel initially opted for a policy of cutting down on the numbers of Palestinians working inside Israel-some of which was justified by the slowdown in the economy, but much of which was still required, especially within the construction industry-and allowing a small number to enter Israel and remain there continuously without returning home at night. However, this proved to be almost impossible to implement, as Israeli employers were either unable or unwilling to provide the necessary sleeping and food arrangements for this group of people, and within weeks the policy was cancelled. Security checks, at times raising serious human rights and ethical considerations at border crossings, remain in operation for those who do continue to cross into Israel on a daily basis, but few medical checks, other than a random temperature check with electronic thermometer, are employed to check for infection. Those Israelis who do travel in and out of the West Bank (including the settler population) are not subject to any security checks and are allowed to travel with their vehicles, which can immediately be identified by their licence plates.

Initially, it was widely assumed in Israel that whatever the rates of infection inside the country, these would be far worse in the West Bank and Gaza Strip, where social and living conditions were far worse and crowding was much higher with a greater risk of mass infection. This partially explains the attempt to ensure that workers, once inside Israel, would remain there for a few weeks without returning home. In reality, however, the West Bank and Gaza Strip did not experience mass outbreak of the virus and, along with the technical difficulties of implementing the new policy, the Israeli government decided to return to its existing policy of daily crossings in and out of the area, albeit at a reduced number, and highly dependent on the changing requirements of the labour market and the opening / closing of the Israeli economy.

Israel's experience was far worse in Phase 2 than in Phase 1. The number of daily infections increased to around 
1000 per day although there are indications that this began to level out and decrease during the latter part of October, leading to a gradual relaxation of the restrictions, including a gradual opening of the airport to a limited number of international flights. Notwithstanding, two week quarantine periods for those entering the country were expanded to include most travellers, all of whom were Israeli citizens returning to Israel. Entry to the country ceased for all non-citizens.

The rise in infection rates in Phase 2 has largely been attributed to the government decision to open up large parts of the economy and the schooling system (the two are obviously related to each other as working parents require their children to be at school or pre-school frameworks if they are to be able to go out to work), along with the beaches, restaurants, pubs and places of worship. The border restrictions largely remained in place, meaning that while much of the first phase infections were due to incoming travellers, the second phase were almost entirely due to internal mixing and the breaking downs of social restriction barriers, especially at places of large gatherings such as prayer houses, beaches, shopping malls and political demonstrations-which increased during the COVID-19 period. Attempts by the government to ban such demonstrations were overturned by the courts as an infringement of the public right to demonstrate, especially as some other groups had the right to congregate, albeit within smaller numbers.
Notwithstanding, while the initial infections and deaths in Phase 1 had a disproportionate impact on the elderly population, and elderly care homes, the larger number of infections in Phase 2 have impacted a much younger population who have been infected at the beach, in the shopping centres and in the pubs. While the total numbers have risen, the severity of the infection appears to be much weaker amongst the younger groups and has not therefore translated into significant mortality rates, which remain low. This is, as yet, an indefinite conclusion, and the longer term impact of the newly infected remains to be seen. Even so, the numbers are sufficient for the hospitals to be filling up and there is a growing fear that, even with the facilities and equipment which is now in place, they will shortly reach saturation point.

\section{Conclusion}

Because of its limited number of border crossing points into the country, Israel has been able to close down the borders with relative ease. The increase in numbers of infections in Phase 2 is more an internal than external problem, resulting from the opening of the economy too soon, not from the number of people entering the country from infected zones, which has anyway almost ceased altogether. 